\title{
Dietary Intake of Children Participating in the USDA Summer Food Service Program
}

\author{
Betty del Rio-Rodriguez ${ }^{1}$ and Karen W. Cullen ${ }^{* 2}$
}

${ }^{1}$ Assistant Professor of Pediatrics, Baylor College of Medicine

${ }^{2}$ Professor of Pediatrics-Nutrition, Baylor College of Medicine

${ }^{*}$ Corresponding author: KW Cullen, Professor of Pediatrics-Nutrition, USDA/ARS Children's Nutrition Research Center, Baylor College of Medicine, 1100 Bates St, Houston, Tel: 713798 6764, E-mail: kcullen@ bcm.edu

Citation: del Rio-Rodriguez B, KW Cullen (2014) Dietary Intake of Children Participating in the USDA Summer Food Service Program. J Nutr Health Sci 1(3): 302. doi: 10.15744/2393-9060.1.302

Received Date: August 05, 2014 Accepted Date: November 03, 2014 Published Date: November 06, 2014

\begin{abstract}
The USDA summer food service program (SFSP) provides free lunches during the summer. This study examined the foods selected and consumed by participating children. Three hundred and two children were observed in 14 schools during a 4-week period in June, 2011; 50\% were male; 75\% were in elementary school. Dietary intake was observed and recorded; selected and consumed foods were entered into nutrient analysis software to obtain selected and consumed nutrients. Meals offered to students met the National School Lunch Program (NSLP) meal patterns. However, students selected meals that were low in Vitamin C, and did not include the two servings of fruit and/or vegetable allowed in the meal pattern. Elementary students consumed a mean of $63 \%$ of energy selected and 0.57 serving of fruit+ vegetables ( 0.29 cup); intermediate students consumed $73 \%$ of energy selected and mean a 0.39 serving of fruit+ vegetables $(0.20$ cup). Food waste was high ( $>30 \%)$ for fruit, vegetables and grains. The SFSP as offered to children met the USDA lunch standards but interventions are needed to improve student food selection and consumption.
\end{abstract}

Keywords: Summer food service meal program; Students; Nutrients; Food groups; Food insecurity

\section{Introduction}

Food insecurity is defined as "the limited or uncertain availability of nutritionally adequate and safe foods or limited or uncertain ability to acquire acceptable foods in socially acceptable ways" [1,2]. In 2012, about $14.5 \%$ of US households were food insecure at least some time during the year, including $5.7 \%$ with very low food security $[3,4]$. Food insecurity is usually higher during the summer months, especially among households with children [5]. Families with school-age children may struggle to provide nutritious food for their children who receive free breakfast and lunch during the school year. The Summer Food Service Program (SFSP) provides free meals during the summer months to all children up to the age of 18 years old living in low-income areas where at least $50 \%$ of children qualify for free and reduced school meals [6]. The SFSP was created as a 3-year pilot in 1968 and made permanent in 1975 [7]. State agencies administer the program and sponsors such as school food authorities, government agencies, summer camps, and non-profit organizations run the program in various sites including schools, parks, community centers, and churches.

All meals served to the children must follow the National School Lunch Program (NSLP) guidelines. Prior to the 2012-2013 school year, NSLP lunches had to meet the applicable recommendations of the Dietary Guidelines for Americans: no more than 30\% of calories from fat, and less than 10\% from saturated fat. School lunches also had to provide one-third of the Recommended Dietary Allowances of protein, Vitamin A, Vitamin C, iron, calcium, and calories. The food pattern offered to children had to include one serving of protein food, 2 servings of fruit and/or vegetables, 1 grain serving, and 8 ounces of milk. A recent study reported that the SFSP has the potential to reduce food insecurity among those with very low food security by as much as 33\% [8].

Unfortunately, poor participation from children and sponsors has been a major obstacle for the program to reach its mission [9]. During the summer of 2012, only 14.3 children received summer meals for every 100 low-income students who received lunch in the 2011-2012 school year [9]. In recent years, efforts have concentrated on increasing program participation; but little research has been published on the nutrition provided by these meals.

Therefore, the objective of this paper is to examine the quality of the SFSP meals selected and consumed by children participating in the program. It was hypothesized that the meals selected and consumed by children participating in the SFSP would meet the NSLP standards. 


\section{Methods and Materials}

This was a cross-sectional study of children participating in a SFSP sponsored one school district during the summer of 2011. This school district is located in the Houston area. At the time of this study, $81 \%$ of the students were Hispanic and $82 \%$ of the students were eligible for free or reduced price meals. Fourteen schools were selected for observation (10 elementary, 2 middle, and 2 intermediate) by the Food Service Director. The study protocol was approved by the Baylor College of Medicine Institutional Review Board. Informed consent was not required for the anonymous observations.

The school cafeterias were open for breakfast and lunch to every child up to 18 years old. For this study, children were observed only during the lunch period. Participating children were enrolled in summer school, summer camp at the school, or walked in from the surrounding community with a parent or by themselves. Selection of children for observation was based on table seating and order, and no more than 4children were observed at the same time by the observer.

The lunch was prepared at the schools by the cafeteria staff. Table 1 illustrates the menu items offered by day. The school utilized the offer versus serve (OVS) option, whereby children only had to select three of the five menu components for the meal to qualify as reimbursable [10]. Prior to the observation, a checklist was created using the lunch menu items as planned by the school district. Observers were trained during one lunch period and used the checklist to note what menu items the child selected in the cafeteria line. During the observation period, the portion $(0,1 / 4,1 / 2,3 / 4$, all $)$ of food items consumed, exchanged and wasted was recorded. The quarter waste method $(0,1 / 4,1 / 2,3 / 4$, all $)$ has high inter-rater and inter-method reliability [11]. No demographic information was collected from the children other than sex and grade level (elementary or intermediate school), and there was no interaction with the children before or during lunch. Children were not aware of the reason of for the presence of the observers in the cafeteria and only the school administration knew the purpose of the visit.

\begin{tabular}{|c|c|c|c|c|}
\hline & $\begin{array}{c}\text { Milk } \\
\text { (1 serving) }\end{array}$ & $\begin{array}{l}\text { Fruits/Vegetables } \\
\text { ( } 2 \text { serving })\end{array}$ & $\begin{array}{c}\text { Grains } \\
\text { (1 serving) }\end{array}$ & $\begin{array}{c}\text { Meat/ Meat Alternate } \\
\text { (1 serving) }\end{array}$ \\
\hline Monday & $\begin{array}{l}\text { White 1\% Fat or } \\
\text { Chocolate Fat-free }\end{array}$ & $\begin{array}{l}\text { Chilled Peaches } \\
\text { Beans (lowfat } \\
\text { refried w cheese) }\end{array}$ & $\begin{array}{c}\text { Soft whole wheat } \\
\text { tortilla } \\
\text { Spanish Rice }\end{array}$ & $\begin{array}{l}\text { Beef taco meat with } \\
\text { cheese }\end{array}$ \\
\hline Tuesday & $\begin{array}{l}\text { White 1\% Fat or } \\
\text { Chocolate Fat-free }\end{array}$ & $\begin{array}{c}\text { Mashed Potatoes } \\
\text { Green Beans } \\
\text { Spiced Apples }\end{array}$ & Dinner roll & $\begin{array}{c}\text { Chicken Nuggets or } \\
\text { Roasted Chicken }\end{array}$ \\
\hline Wednesday & $\begin{array}{l}\text { White } 1 \% \text { Fat or } \\
\text { Chocolate Fat-free }\end{array}$ & $\begin{array}{l}\text { Peas or Corn } \\
\text { Pear Cup }\end{array}$ & $\begin{array}{c}\text { Whole Wheat } \\
\text { bread } \\
\text { Cookie }\end{array}$ & $\begin{array}{l}\text { Grilled Cheese } \\
\text { Sandwich }\end{array}$ \\
\hline Thursday & $\begin{array}{l}\text { White } 1 \% \text { Fat or } \\
\text { Chocolate Fat-free }\end{array}$ & $\begin{array}{l}\text { Baked French Fries } \\
\text { Pickle Spears } \\
\text { Rosy Applesauce }\end{array}$ & Whole wheat buns & $\begin{array}{l}\text { Cheeseburger or } \\
\text { Hamburger patty }\end{array}$ \\
\hline
\end{tabular}

Note: Serving sizes consist of: 1 cup of fluid milk; $3 / 4$ cup of fruits/ vegetables; 1 slice of bread or 1 serving of roll or $1 / 2$ cup of grains; 2 oz. of lean meat or poultry or alternate protein product or cheese; $1 / 2$ cup of cooked dry beans or peas; 4 Tbsp. peanut butter.

Table 1: One-Week Four-Day Cycle Menu and Lunch Meal Pattern for the SFSP

For each lunch observation form, the foods selected and consumed for each student were entered into separate Nutrition Data System for Research files (version 2010, Nutrition Coordinating Center, University of Minnesota, MN) by trained dietitians to obtain lunch intake of selected and consumed nutrients and food groups. The mean amounts of nutrients and food groups selected and consumed by grade level were calculated. The percentage of the food groups consumed was calculated by dividing the amount consumed by the total amount selected. The percentage of food groups wasted was calculated by subtracting the percent consumed from $100 \%$. Differences in the percentage of food groups consumed by grade level were assessed with independent $t$ tests or MannWhitney tests (for non-normal distribution) depending on distribution. SPSS (IBM SPSS Statistics for Windows, Version 19.0. Armonk, NY: IBM Corp) was used for all calculations.

\section{Results}

Three hundred and two $(\mathrm{N}=302)$ children were observed during a four-week period in the 14 schools. 50\% were male and $75 \%$ were in elementary grades. Parents attended with 62 elementary school students (26\%). Most of the students eating lunch attended summer school (73\% elementary and $86 \%$ intermediate).

The mean amounts of nutrients in the meals selected by the elementary school students $(n=240)$ met the USDA NSLP standards for all nutrients except energy and vitamin C (Table 2). The mean amount of fruit and vegetables selected by the students was 1.1 servings per meal, not the two servings that were allowable for the meal. Only 53\% selected at least one fruit and 76\% selected at least one vegetable. The elementary school students did not consume adequate energy, iron, vitamins $\mathrm{A}$ and $\mathrm{C}$, or the various food groups to meet the NSLP standards (Table 2). Elementary school students consumed only $64 \%$ of energy in the meals they selected, reflecting a wasting of almost one third of the kcals selected (Table 4). The percentages of fruit and vegetables consumed were $61 \%$ and $44 \%$, respectively, which reflects wastes of $39 \%$ of fruit and $56 \%$ of vegetables selected. 


\begin{tabular}{|c|c|c|c|c|c|}
\hline & \multirow[t]{2}{*}{$\begin{array}{l}\text { USDA Lunch } \\
\text { Standard }\end{array}$} & \multicolumn{2}{|c|}{$\begin{array}{l}\text { Nutrients and Foods } \\
\text { Selected }\end{array}$} & \multicolumn{2}{|c|}{$\begin{array}{c}\text { Nutrients and Foods } \\
\text { Consumed }\end{array}$} \\
\hline & & Mean & $\mathrm{SD}^{1}$ & Mean & SD \\
\hline Energy & 633 & 611 & 90 & 387 & 152 \\
\hline Protein (gram) & 9 & 40 & 10 & 26 & 13 \\
\hline$\%$ Energy from Fat & $<30 \%$ & 25 & 4 & 24 & 7 \\
\hline \% Energy from Saturated Fat & $<10 \%$ & 9.2 & 2.1 & 8.7 & 3.3 \\
\hline Calcium (milligram) & 267 & 578 & 273 & 400 & 252 \\
\hline Iron (milligram) & 3.3 & 4.3 & 1.5 & 2.6 & 1.5 \\
\hline Vitamin A (Retinol Equivalent) & 200 & 273 & 90 & 190 & 88 \\
\hline Vitamin C (milligram) & 15 & 10.4 & 8.4 & 5.5 & 6.9 \\
\hline Sodium (milligram) & none set & 1500 & 371 & 936 & 460 \\
\hline Total Dietary Fiber (gram) & none set & 6.5 & 2.8 & 3.7 & 2.1 \\
\hline Fruit (serving) & \multirow{2}{*}{$\begin{array}{l}2 \text { total fruit } \\
\text { and vegetables }\end{array}$} & 0.28 & 0.26 & 0.17 & 0.23 \\
\hline Total Vegetables (serving) & & 0.83 & 0.67 & 0.40 & 0.65 \\
\hline Grains (serving) & 1 & 2.20 & 1.12 & 1.20 & 0.90 \\
\hline Whole grains (serving) & none set & 0.88 & 1.07 & 0.44 & 0.65 \\
\hline Protein Foods (ounce) & 2 & 2.2 & 2.1 & 1.4 & 1.7 \\
\hline Milk (ounce) & 8 & 7.6 & 1.8 & 6.0 & 2.7 \\
\hline
\end{tabular}

Table 2: Mean Amounts of Calories and Foods Selected and Consumed at Lunch by 240 Elementary School Students in the 10 Schools Participating in the Summer Food Service Program, Summer, 2011

\begin{tabular}{|c|c|c|c|c|c|}
\hline & \multirow[t]{2}{*}{$\begin{array}{l}\text { NSLP lunch } \\
\text { Standard }\end{array}$} & \multicolumn{2}{|c|}{$\begin{array}{l}\text { Nutrients and Foods } \\
\text { Selected }^{\mathrm{a}}\end{array}$} & \multicolumn{2}{|c|}{$\begin{array}{l}\text { Nutrients and Foods } \\
\text { Consumed }^{\mathrm{b}}\end{array}$} \\
\hline & & Mean & $\mathrm{SD}$ & Mean & SD \\
\hline Energy & 785 & 628 & 85 & 450 & 231 \\
\hline Protein (gram) & 15 & 38 & 7 & 28 & 17 \\
\hline$\%$ Energy from Fat & $<30 \%$ & 25 & 5 & 24 & 9 \\
\hline$\%$ Energy from Saturated Fat & $<10 \%$ & 9.00 & 1.80 & 8.40 & 3.20 \\
\hline Calcium (milligram) & 370 & 639 & 251 & 493 & 361 \\
\hline Iron (milligram) & 4.20 & 4.20 & 1.30 & 2.80 & 1.70 \\
\hline Vitamin A (Retinol Equivalent) & 285 & 299 & 84 & 222 & 141 \\
\hline Vitamin C (milligram) & 17 & 4.90 & 5.30 & 3.20 & 6.00 \\
\hline Sodium (milligram) & none set & 1678 & 416 & 1168 & 695 \\
\hline Total Dietary Fiber (gram) & none set & 8.00 & 2.80 & 5.20 & 3.10 \\
\hline Fruit (serving) & \multirow{2}{*}{$\begin{array}{l}2 \text { total fruit } \\
\text { and vegetables }\end{array}$} & 0.29 & 0.28 & 0.21 & 0.28 \\
\hline Total Vegetables (serving) & & 0.31 & 0.49 & 0.18 & 0.56 \\
\hline Grains (serving) & 1 & 2.90 & 0.80 & 1.96 & 1.20 \\
\hline Whole grains (serving) & none set & 1.96 & 1.05 & 1.20 & 1.10 \\
\hline Protein Foods (ounce) & 2 & 1.50 & 1.67 & 1.20 & 1.80 \\
\hline Milk (ounce) & 8 & 7.10 & 2.60 & 5.70 & 1.96 \\
\hline
\end{tabular}

${ }^{\mathrm{a}} \mathrm{n}=62{ }^{\mathrm{b}} \mathrm{n}=59$ ( 3 students did not eat their selected meals.)

Table 3: Mean Amounts of Calories and Foods Selected and Consumed at Lunch by 62 Intermediate School Students in the 10 Schools Participating in the Summer Food Service Program, Summer, 2011 
The intermediate school students $(n=62)$ did not select foods that met the USDA NSLP energy or vitamin C standards, nor did they select two servings of total fruit and vegetables or 2 ounces of protein foods as per the NSLP meal pattern (Table 3). Only 55\% and $46 \%$ selected at least one fruit or vegetable for lunch, respectively. Three intermediate school students did not consume their lunch. Those records were deleted from the consumption analyses. Intermediate school students did not consume enough energy, iron, or vitamins A and C to meet the NSLP standards (Table 3). They only consumed only $73 \%$ of energy selected, about $65 \%$ and $33 \%$ of fruit and vegetables selected, respectively (Table 4). These values represent wasting $25 \%$ of energy selected, $35 \%$ of fruit and $67 \%$ of vegetables. There were no significant differences in percentage of food groups consumed by grade level.

\begin{tabular}{|c|c|c|}
\hline \multirow{2}{*}{} & \multicolumn{2}{|c|}{ Mean percent consumed } \\
\cline { 2 - 3 } & Elementary & Intermediate \\
\hline Energy & 64 & 73 \\
\hline Fruit (serving) & 61 & 65 \\
\hline Total Vegetables (serving) & 44 & 33 \\
\hline Grains (serving) & 59 & 69 \\
\hline Whole grains (serving) & 54 & 64 \\
\hline Protein Foods (ounce) & 66 & 66 \\
\hline Milk (ounce) & 78 & 77 \\
\hline
\end{tabular}

No significant differences in percentage of food groups consumed by grade level.

Table 4: Percent of Energy and Food Groups Consumed at Lunch by 240 Elementary and 62 Intermediate School Students in the 14 Schools Participating in the Summer Food Service Program, Summer, 2011

\section{Discussion}

This study assessed the nutrients and food groups selected and consumed by elementary and intermediate school students participating in the SFSP. The SFSP meals as offered to the students in this study met the NSLP meal patterns. Only two previous studies were found that assessed SFSP lunches. In a 2001 study, observers recorded the foods selected and leftover for SFSP lunches [6]. The meals served to the students met all the nutrient and food group standards, except for fat and saturated fat. Similar findings were reported with a plate waste study on SFSP meals consumed by youth in Delaware [12].

Neither the elementary or intermediate school students in this current study selected foods with enough energy or vitamin C; the intermediate students also did not select enough protein foods. The greatest proportion of food waste by elementary and intermediate school students was for fruit (39-35\%), vegetables (56-67\%), and grains (41-31\%) (Tables 2 and 3). This waste contributed to the inadequate lunch consumption of kilocalories, iron, vitamins A and C, compared to the NSLP meal standards. The student plate waste results are very similar to a national study where about $32 \%$ of calories, $36 \%$ of meat, $37 \%$ of fruit, $39 \%$ of bread, and $48 \%$ of vegetables were wasted [6]. In Delaware, the mean amount of calories selected was 668; the mean amounts consumed ranged from 375-440 for the 4-13 year old children; and the authors estimated that $38 \%$ of kilocalories were wasted [12].

In 2002, 203 interviews and two focus groups about the SFSP menus were conducted with Delaware SFSP participants [12]. The major reason reported for wasting foods was dislike of the items served. Perceptions of food quality were also important. Items that were smashed, soggy, or frozen were rejected, as was warm milk [12]. The involvement and support of the SFSP vendor, school, and parents are needed. Promising strategies to promote consumption of new foods include taste testing, signage promoting the foods being served and marketing [13-15].

Other reasons for the food waste include whether the foods were culturally acceptable to this predominately Hispanic population. Children also prefer energy dense high fat foods [16]. Perhaps the children were not used to the fruit, vegetables, and low fat milk on the menu. This is an important area for future research. Sodium intake was high for both grade levels, something not discussed in previous SFSP studies. New NSLP standards include sodium limits with a target implementation date of 2023 [Lunch meals $\leq 640 \mathrm{mg}$ (grades K-5); $\leq 710 \mathrm{mg}$ (grades 6-8); $\leq 740 \mathrm{mg}$ (grades 9-12)] [17]. These values are substantially lower than the 936 and $1168 \mathrm{mg}$ consumed in this study. Because most sodium (75\%) in school meals comes from processed foods like combination entrees and accompaniments, new lower sodium products and recipes that are acceptable to students will be needed [18], creating a need for a very important area for future research.

Plate waste and not selecting fruit and vegetables are also issues for lunches served during the school year. In a Texas study with middle school students who completed lunch records in the cafeteria, $40.2 \%$ consumed fruit and $66.9 \%$ consumed vegetables [19]. Actual lunch consumption was 0.89 serving of total vegetables ( 0.45 cup) (excluding high-fat vegetables), 0.45 serving fruit and juice ( 0.23 cup), and 6.5 ounces of milk during the 2005-2006 school year [20]. These results identify the need for nutrition education and marketing efforts both during the school year and during the summer programming. 
There are several limitations that should be noted. The study took place in one school district in South Texas, limiting generalizability. Only gender and grade level were recorded; information on ethnicity and parent demographics were not collected, reducing the outcomes that could be reported. Diet for the entire day was not recorded, so the impact of this meal on total day's intake was not assessed. Future studies should include dietary intake for the entire day. However, the observation method used to record intake is an important strength of the study, as it reduces error from remembering foods consumed in previous meals. Finally, new school meal guidelines were implemented in the fall of 2012,that aligned the meal patterns to the 2010 US Dietary Guidelines [21, 22]. These changes increased to three ( 1 fruit and 2 vegetables) that are allowed for a reimbursable lunch meal, as well as increase the number of whole grain foods on the menu. The level of sodium must be decreased over a ten year period. These changes may impact food selection and consumption for the SFSP; further research is warranted.

\section{Conclusion}

The SFSP is an important program that should improve child food security and nutrition during the summer months when school is not in session. However, not all children have the opportunity to receive summer meals because of low participation by sponsors during the summer months. Also food waste is a concern. Further research is needed to increase SFSP program availability and to improve consumption of the meal.

\section{Acknowledgment}

This work is a publication of the USDA/ARS Children's Nutrition Research Center, Department of Pediatrics, Baylor College of Medicine, Houston, Texas. This project has been funded in part by federal funds from the USDA/ARS under Cooperative Agreements No. 143-3AEL-2-80121 and 58-6250-6001. The contents of this publication do not necessarily reflect the views or policies of the USDA, nor does mention of trade names, commercial products, or organizations imply endorsement by the U.S. Government.

\section{References}

1. United States (2014) Department of Agriculture - Economic Research Service. Food security in the U.S: Key statistics \& graphics.

2. Hamilton WL, Cook JT, Thompson WW, Buron LF, Frongillo EA, et al. (1997) Household food security in the United States in 1995: Summary report of the Food Security Measurement Project. Alexandria, VA: Food and Consumer Service, U.S. Department of Agriculture.

3. Coleman-Jensen A, Nord M, Andrews M, Carlson S (2012) Household food security in the United States in 2011. United States Department of Agriculture Economic Research Service.

4. Coleman-Jensen A, Nord M, Singh A (2013) Household food security in the United States in 2012. United States Department of Agriculture - Economic Research Service.

5. Nord M, Romig K (2006) Hunger in the summer: Seasonal food insecurity and the National School Lunch and Summer Food Service programs. J Child Poverty 12: 141-58.

6. Gordon A, Briefel R(2003) Feeding low-income children when school is out-The Summer Food Service Program: Executive summary.

7. Department of Agriculture -Food and Nutrition Service (2013) Program History-Summer Food Service Program. United States.

8. Department of Agriculture - Economic Research Service (2013) SummerFood Service Program distribution sites and average daily attendance in July, fiscal 1989-2013. United States.

9. Burke M, Sims K, Anderson S, FitzSimons C, Hewins J (2013) Hunger doesn’t take a vacation: Summer nutrition status report 2013. Food Research and Action Cente.

10. Food and Nutrition Service - US (2000) Department of Agriculture. Menu planning in the National School Lunch Program.

11. Hanks AS, Wansink B, Just DR (2014) Reliability and accuracy of real-time visualization techniques for measuring school cafeteria tray waste: Validating the quarter-waste method. J Acad Nutr Diet 114: 470-4.

12. Cotugna N, Vickery CE (2004) Children rate the Summer Food Service Program. Fam Econ Nutr Rev 16: 3-12.

13. Fulkerson JA, French SA, Story M, Nelson H, Hannan PJ (2004) Promotions to increase lower-fat food choices among students in secondary schools: Description and outcomes of TACOS (Trying Alternative Cafeteria Options in Schools). Public Health Nutr 7: 665-74.

14. Snyder P, Anliker J, Cunningham-Sabo L, Dixon LB, Altaha J, et al. (1999) The Pathways study: a model for lowering the fat in school meals. Am J Clin Nutr 69: 810S-5S.

15. Wechsler H, Basch CE, Zybert P, Shea S (1998) Promoting the selection of low-fat milk in elementary school cafeterias in an inner-city Latino community: Evaluation of an intervention. Am J Public Health 88: 427-33.

16. Birch LL (1992) Children's preferences for high-fat foods. Nutr Rev 50: 249-55.

17. Food and Nutrition Service - U.S (2012) Department of Agriculture. Nutrition standards in the National School Lunch and School Breakfast Programs. Final rule. Fed Regist 77: 4088-167.

18. Gordon A, Crepinsek MK, Nogales R, Condon E (2007) School nutrition dietary assessment study III: Volume I: School foodservice, school food environment, and meals offered and served. Washington, D.C, United States Department of Agriculture - Food and Nutrition Service.

19. Cullen KW, Watson KB, Dave JM ( 2011) Middle-school students'school lunch consumption does not meet the new Institute of Medicine's National School Lunch Program recommendations. Public Health Nutr 14:1876-81. 
20. Cullen KW, Watson K, Zakeri I (2008) Improvements in middle school student dietary intake after implementation of the Texas Public School Nutrition Policy. Am J Public Health 98:111-7.

21. Stallings VA, Suitor CW, Taylor CL (2009) School Meals: Building Blocks for Healthy Children. Institute of Medicine/The National Academies Press. Washington, D.C, USA.

22. Food and Nutrition Service - U.S (2010) Department of Agriculture. Healthy, Hunger- Free Kids Act of 2010.

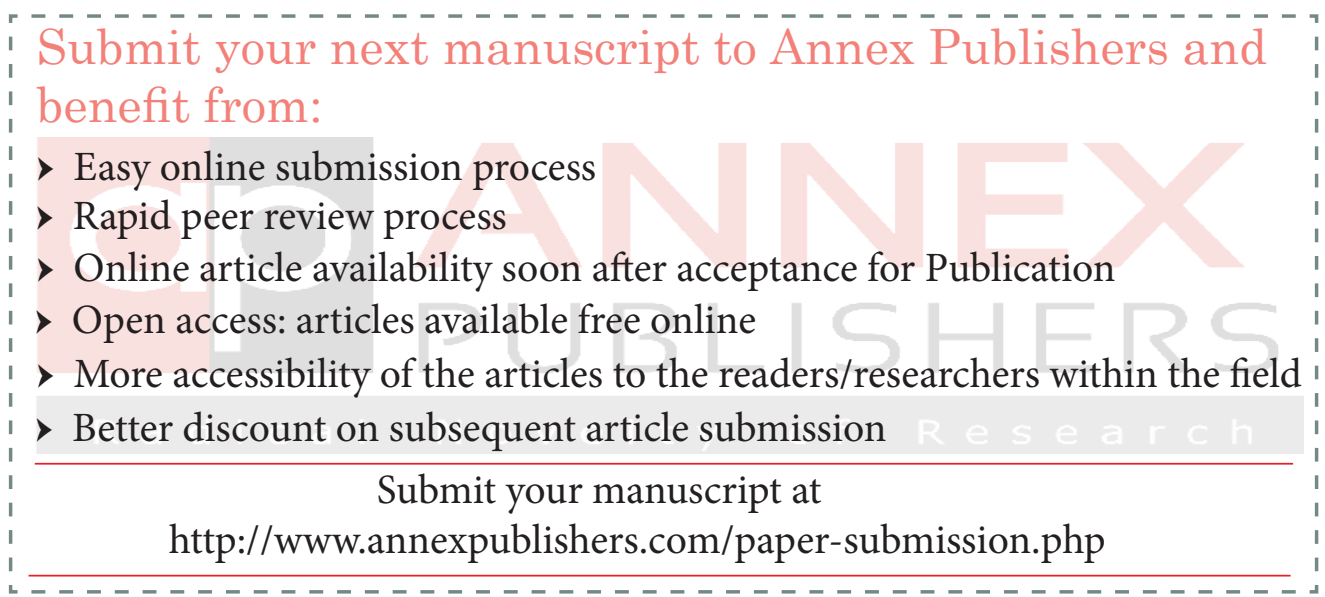

